\title{
THE RECOGNITION OF EXISTENCE AND BIBLICAL TRUTH IN THE PERSPECTIVE OF THE QUR'AN (Critical Study of the Development of Liberal Islamic Thought in Indonesia)
}

\author{
Asep Setiawan \\ Universitas Muhammadiyah Yogyakarta \\ Email: asep.setiawan@umy.ac.id
}

\begin{abstract}
This article seeks to highlight and provide answers to the controversial opinions that have recently been frequently campaigned by some liberal Muslim figures that the Qur'an recognizes the existence and truth of previous scriptures such as the Bible. They use several verses in the Qur'an, 5:44, 46-47 and 66, to justify the above opinions supported by partial interpretation experts under their understanding and purpose. In this study, the author used the library research method, which is research-based on library studies. The approach used is descriptiveanalytical, which describes existing data sources, then analyzed and interpreted using available data sources. The opinion of liberal Islamic thinkers that it is enough for the Jews to use the Torah in carrying out religious law, and the Christians that they simply follow the rules in the Bible, this is because their methodology in understanding the verse is wrong. They did not explain at all the abuses committed by Jews and Christians. Including their defiance of Allah's command and about the guidance of the coming of the Prophet Muhammad with his perfect and universal sharia, which they are obliged to follow and obey, which is the information contained in their holy book. In understanding the verses of the Qur'an, they do not use methodological steps that can be accounted for in the discipline of interpretation. Contextual schools are emphasized for several texts that are alleged to be anti-religious pluralism. While on the other hand, literal schools are applied to verses that support the notion of religious pluralism.
\end{abstract}

Keywords: bible; distortion; interpretation; liberal Islam

\begin{abstract}
Abstrak
Artikel ini berupaya untuk mengetengahkan dan memberikan jawaban atas pendapat kontroversial yang belakangan ini sering dikampanyekan oleh beberapa tokoh muslim liberal bahwa al-Qur'an mengakui eksistensi
\end{abstract}


dan kebenaran kitab suci sebelumnya seperti Bibel. Mereka menggunakan beberapa ayat dalam QS. Al-Ma'idah [5]: 44, 46-47, dan ayat ke-66 untuk menjustifikasi pendapat di atas didukung dengan menukil pendapat dari para ahli tafsir secara parsial sesuai dengan paham dan tujuan mereka. Pada penelitian ini, penulis menggunakan metode library research, yakni penelitian yang didasarkan pada studi pustaka. Adapun pendekatan yang digunakan adalah deskriptif-analitis, yaitu mendeskripsikan sumber data yang ada, kemudian dianalisis dan diinterpretasikan dengan menggunakan sumber data yang tersedia. Pendapat para pemikir Islam liberal bahwa kaum Yahudi cukup berhukum dengan Taurat begitu pula kaum Nasrani, yang katanya cukup berhukum dengan Injil atau Bibel, dikarenakan mereka cacat secara metodologis dalam memahami ayat tersebut. Mereka sama sekali tidak menerangkan tentang penyelewengan yang dilakukan orang-orang Yahudi dan Nasrani. Termasuk tentang pembangkangan mereka terhadap perintah Allah dan tentang petunjuk akan datangnya Nabi Muhammad saw. dengan syariatnya yang sempurna dan universal yang wajib diikuti dan ditaati oleh mereka, yang mana informasi tersebut terdapat di dalam kitab mereka. Dalam memahami ayat-ayat al-Quran, mereka tidak menggunakan ukuran metodologis yang dapat dipertanggungjawabkan secara disiplin ilmu tafsir. Mazhab kontekstual ditekankan untuk sejumlah teks yang diduga anti kemajemukan beragama. Sementara di sisi lain, mazhab literal diterapkan untuk ayatayat yang mendukung paham pluralism agama.

Kata kunci: bibel; distorsi; islam liberal; tafsir

\section{Introduction}

Among the controversial opinions expressed by liberal thinkers in Indonesia is about the recognition of the existence and truth of the holy books before the Qur'an. ${ }^{1}$ They claim that the Bible is a holy book whose existence and truth are recognized by the Qur'an. To strengthen their opinion, they cited several verses in the Qur'an as evidence of the above confession, namely the Qur'an surah al-Maidah (5) verses 44, 46-47 and verse 66. Based on

${ }^{1}$ One of them is a statement from Abdul Moqsith Ghazali. In his book, Moqsith writes in one of the sub-chapters of his book, "Pengakuan eksistensi dan kebenaran kitab-kitab sebelum Islam", see Abdul Moqsith Ghazali, Argumen Pluralisme Agama: Membangun Toleransi Berbasis Al-Qur'an (Jakarta: Kata Kita, 2009), p. 241.

402 | TAJDID vol. 20, No. 2, Juli - Desember 2021 
these verses, liberal thinkers argue that the Qur'an gives recognition to Jews and Christians. In a sense, it is enough for them to make their holy books as a basis for their religion and morals. As Abdul Moqsith also said that the Torah is not only a reference to the Prophet Musa, and his people, but also a reference to the prophets who were not accompanied by a holy book by starting with the opinion of al-Qurtubi on the interpretation of the word al-nabiyyun in the Qur'an, 5:44.

Moqsith argues that the Qur'an, 5:66, was revealed to remind the Jews to return to the law that has been established in Torah. In addition, what is interesting, according to him, is that after the Qur'an explains about the Torah and the Gospel, then the next verse (Qur'an, 5:48) explains about the Qur'an which was sent down to the Prophet Muhammad, serves as a justification (mushaddiq) for the two books. This, according to him, is a form of open acknowledgement by Muslims of the previous holy books. ${ }^{2}$

Is the Bible same and in accordance with the Torah or Injil mentioned in the Qur'an? Is it acceptable for the opinion of liberal thinkers who state that it is enough for the Jews and Christians to use their respective holy books as a reference in their religion and their moral basis? Is the Torah which is believed by Jews today and the Bible which is believed to be true by Christians today, really worthy to be believed because it is still original as it was when it was revealed? What is the position of both after the descent of the Qur'an and the sending of the Prophet Muhammad? Departing from the above problems, this simple writing seeks to provide criticism and correction of the understanding of liberal thinkers which in this case is the opinion of Abdul Moqsith Ghazali in the book Argumen Pluralisme Agama: Membangun Toleransi Berbasis AlQur'an.

In this paper, the author uses the library research method, which is research based on library studies. The primary book used

2 Abdul Moqsith Ghazali, Argumen Pluralisme Agama, p. 241-243.

TAJDID vol. 20, No. 2, Juli - Desember 2021 | 403 
as a reference is Argumen Pluralisme Agama, while the secondary books are supporting books from various writings, such as textbooks both Indonesian and Arabic, journal articles, Arabic dictionary, and the like. The approach method used is descriptiveanalytical, which describes existing data sources, then analyzed and interpreted using available data sources.

\section{Discussion}

\section{Obligation to Believe in the Scriptures and the Prophets}

In the teachings of Islam, Allah not only commands his people to believe in the Qur'an, or only to the Prophet Muhammad as the last Prophet who taught and preached Islam to his people, but also told them to believe all the holy books that were handed down to the prophets, ${ }^{3}$ of all the nations of the world. ${ }^{4}$ Some of them are mentioned and some are not mentioned..$^{5}$ Those related, for example, Prophet Adam, ${ }^{6}$ Idris, ${ }^{7}$ Ibrahim, Ishak, Ya'kub, Nuh, Dawud, Sulaiman, Yusuf, Ayub, Musa, Harun, ${ }^{8}$ Zakaria, Yahya, Isa, Ilyas, ${ }^{9}$ Ismail, Ilyasa, Yunus, and Luth. ${ }^{10}$ It's all told in the Bible. While the prophet is not told in the Qur'an, for example: Joshua, Isaiah, Yermia, Ezekiel, Daniel and so on. The number of prophets and apostles is estimated at 124,000 prophets and 315 apostles. ${ }^{11}$ The faith in all the books and

\footnotetext{
${ }^{3}$ Qur'an, 2:4, and 2:213.

${ }^{4}$ Qur'an, 10:47, and 16:36.

${ }^{5}$ Qur'an, 4:164, and 40:78.

${ }^{6}$ Qur'an, 19:58.

${ }^{7}$ Qur'an, 19:56.

${ }^{8}$ Qur'an, 6:84-85.

${ }^{9}$ Qur'an, 6:86.

${ }^{10}$ Qur'an, 6:87.
}

11 As quoted by Moqsith in Hasan al-Shaffar, al-Ta'addudiyat wa al-Huriyat fi al-Islam (Beirut: Dar al-Bayan al-'Arabi, 1990), p. 14. In the narration of Abu Umamah, that Abu Dharr asked the Prophet shallallabu 'alaibi wa sallam: "What is

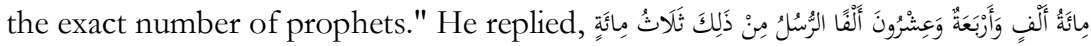

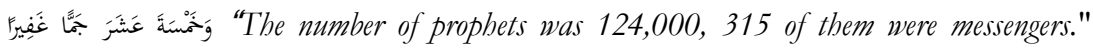
(HR. Ahmad) 
prophets in Islam is part of the pillars of faith that must be believed by every Muslim. ${ }^{12}$ In Islam, believing in the prophet and believing in the books that were revealed to him are separated because not all prophets were given the revelation of the holy book.

According to the author, Moqsith's statement that "Islam recognizes the bearers of previous religions such as Moses and Jesus al-Masih" is inaccurate. Because, his statement seems to imply that only the Prophet Muhammad the one who brought the religion of Islam while the Prophet Musa brought other religions, namely Judaism and Prophet Isa bring Christianity. Moqsith and other liberal thinkers stated that these three religions, namely Judaism, Christianity and Islam, belong to the Abrahamic family that lead to the same goal of the world and the hereafter. So by paying attention to the similarity of this goal, the differences that exist between each other need not be confused because one with the other has their own characteristics, peculiarities and uniqueness. ${ }^{13}$ Whereas in the Qur'an, there are many verses which explain that the religion of all prophets and messengers, since the Prophet Adam until the last Prophet is the religion of Islam.

In the Qur'an, it is explained that all prophets and apostles from the beginning to the last, the Prophet Muhammad are Muslims (carrying and proclaiming Islamic treatises). Noah, it is explained that he taught Islam, Qur'an, 10:72. It is also explained that Prophet Ibrahim also brought the teachings of Islam and bequeathed it to his descendants, including to the descendants of Ya'qub or Isra'il, Qur'an, 2:130-132. Among the children of Yaqub is Yusuf, he prayed to Allah that he would die as a Muslim, Qur'an, $10: 84 .^{14}$ al-Ihsan.

${ }^{12}$ HR. Bukhari no. 50, and Muslim no. 9, Bab Bayan al-Iman wa al-Islam wa

13 Abdul Moqsith Ghazali, Argumen Pluralisme Agama, p. 240.

14 Nurcholish Madjid, Pintu-Pintu Menuju Tuhan (Jakarta: Paramadina, 1994), p. 2-3.

TAJDID vol. 20, No. 2, Juli - Desember 2021 | 405 
In another verse, it is also explained that the Egyptian magicians originally supported Pharaoh, but finally they believed in Moses and pray that he will die as a Muslim, Qur'an, 7:126. Then the queen of Bilqis from Yemen, South Arabia, who was conquered by the Prophet Sulaiman, in the end, submitted and obeyed her prophet and declared that she had surrendered completely to Islam to God in the world, Qur'an, 27:44. And all the prophets of The Banu Isra'il (descendants of Yaqub) are explained in the Qur'an that they are all Muslims, Qur'an, 5:44. It's also Isa, he educated his faithful followers (al-bawariyyun) so that they become resigned, surrendering to Allah (Muslim), Qur'an, 3:52-53 and 5:111..$^{5}$

It is also explained that the whole universe and its contents, all of which are submissive, obedient and surrendered (embroidered) to Allah, Qur'an, 3:83-85. When the Jews and Christians scramble to claim that the Prophet Ibrahim is a follower of their religion, Allah refuted them and said that he is a Muslim, as His Word says:

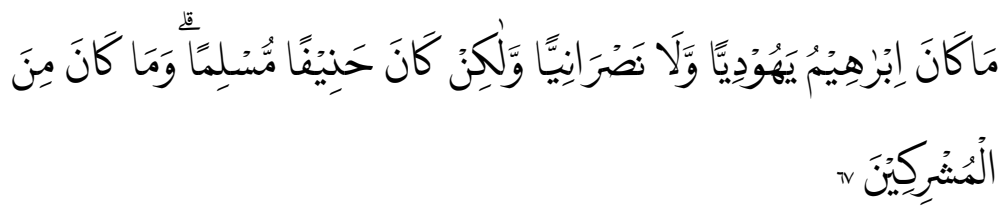

"Abraham was neither a Jew nor a Christian, but he was one inclining toward truth, a Muslim [submitting to Allah]. And he was not of the polytheists." (Qur'an, 3:67) ${ }^{16}$

From the above presentation, it is clear that all the prophets and apostles sent by Allah, all carry the same religion that is Islam. No one of the prophets or apostles was found who brought other religions such as Judaism, Nashrani, Buddhism, Hinduism or other

15 Tim Penyusun Paramadina, Nurcholish Madjid et all., Fiqih Lintas Agama; Membangun Masyarakat Inklusif-Pluralis (Jakarta: Paramadina, 2004), p. 40.

${ }^{16}$ Yunahar Ilyas. "Menyoal Pluralisme Agama", Tabligh; Menyatukan Visi dan Misi Umat, vol. 2. No. 09, April 2004, p. 9. 
religions. So it can be said that Islam brought by the Prophet Muhammad (peace be upon him), is not a new religion, but is the last link of the series of religions that Allah revealed to the prophets and apostles before. Because Islam is the last link in the chain of religions that was revealed by Allah to the earlier prophets and apostles, it is not surprising that in the Qur'an there are teachings that were also mentioned in the previous revelation books because they are all the same, that is from Allah. ${ }^{17}$

\section{A Glimpse of the Bible}

Before discussing the relationship of the Holy Qur'an with the previous scriptures, it is necessary for the author to present a discussion about the Bible, in order to be clearer in its present existence. The Torah and the Gospel are the two holy books before the Qur'an that are often mentioned in the Qur'an. ${ }^{18}$ As for now, the two books are more famously known as the Bible or Alkitab (Indonesia), Kitab Suci (Java), or the Bible (English). The Bible consists of two parts ${ }^{19}$ these are: The Old Testament is $2 / 3$

${ }^{17}$ Related to this the Prophet (peace be upon him), said:

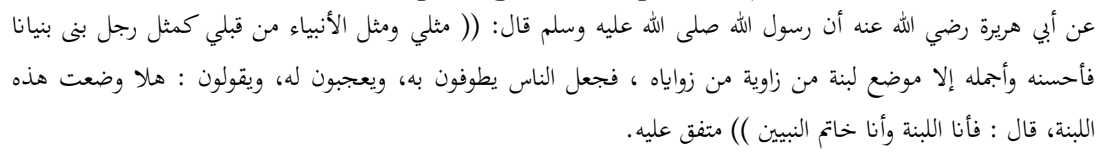

From Abu Hurayrah, that the Prophet said, "My parable and the parable of the prophets before me were like someone who built a building, where be built it beautifully and nicely, there is another stone that has not been installed in one corner, people circling the building enjoy its beauty, they say, "Duhai if only one of these stones is installed! I am the stone and I am the cover of the Prophets." (Muttafaq 'Alaib) See Manna' Khalil Al-Qaththan, Mababis fi 'Ulum al-Qur'an. (Riyadh: Muassasah al-Risalah, 1976), p. 17.

18 Besides the Torah and the Gospels, there is also a verse that describes Abraham and the Prophet Moses receiving a revelation from God called shubuf (Qur'an, 87:18-19), and also the Prophet Dawud who received the book Zabur (Qur'an, 4:163, 17:55, and 21:105). S. Ali Yasir, "Kristologi Qur'ani (alNashraniyyah fi al-Qur'an)", Modul Kristologi Islami Departemen Agama Daerah Istimewa Yogyakarta, Yogyakarta, 1988, p. 56-57.

19 As for the details of the books, chapters and verses in the Bible, in full and detailed and the tables have been studied and analyzed in depth in the bible. S. Ali Yasir, "Kristologi Qur'ani (al-Nashraniyyah fi al-Qur'an)", p. 59-61. See more Muhammad Izzat Ismail al-Thanthawi, Mubammad Nabiyy al-Islam fi al- 
of the Bible consisting of 39 books, namely Torat Musa, the book of the prophets, and Mazmur (Lukas 24:44). It is God's message to the Jews. And the New Testament which is $1 / 3$ of the Bible consisting of 27 books believed to be the fulfillment of Old Testament prophecies about the coming of Jesus Christ or the Messiah (Matius 26: 28, and Ibrani 13: 20). The ultimate message is to believe in Jesus (Kisah Para Rasul 16: 31). ${ }^{20}$

Please note that the understanding of scripture between Muslims and others (in this context Jews and Christians) is very different. An example is the understanding of the Gospel. Among Christians, (among their internal circles there is also a difference) some say that the whole New Testament is the Gospel. And others argue that the Gospels are the first four books of the New Testament written by Matius, Markus, Lukas and Yohanes (Yahya) that tell (some) the teachings and stories of Jesus. ${ }^{21}$

Thus, the Gospel is the work of some early Christian authors whose writing was not intended to be a scripture. Among Christians, they also understand that the Gospel is not a revelation as Muslims understand its holy book (the Qur'an) as kalamullah, in the form of revelation from Allah delivered to the Prophet

Taurah wa al-Injil wa al-Qur'an, Rahasia Mubammad dalam Taurat dan Injil terj. Abu Nabil (Jakarta: Bina Rena Pariwara), p. 123-126.

20 The term Bible (Latin: Biblia, meaning booklet, Greek: Biblos), is used by Jews and Christians to refer to their scriptures. However, there is a difference between the two religions. Jews disagree with Christianity who term the Torah with The Old Testament, because the term means that God's covenant with Jews is an Old Testament that has been removed and replaced withthe New Testament with the coming of Jesus that Christians see as saviors. While the Jews reject the claim of Jesus as Savior. See Adian Husaini, "Problem Teks Bible dan Hermeneutika" Majalah Pemikiran dan Peradaban Islam; Islamia, I, Maret, 2004, p. 7. In the eyes of the Jews, the Gospel is not the word of God, so they consider Christians to be not to be good and true, and vice versa, Christians consider that the Jews are the ones who are heretical because they reject the gospel. And in fact both of them deviated from the path of truth because they did not follow the Torah and the Gospel and the holy book that was revealed after that, namely the Qur'an, 5:68.

21 Huston Smith, The Religions of Man, Agama-Agama Manusia terj. Saafroodin Bahar (Jakarta: Yayasan Obor Indonesia, 2004), p. 358. 
Muhammad through the intercession of the angel Gabriel. ${ }^{22}$ Therefore, besides being able to find the gospel of the four authors above, there is also a letter of Paul's delivery to the people of Rum, Coentius, Galatians, Epesus and others. According to Christian theology, what revelation says is the force that drives the authors of the Gospel and the letter to write each other's work. ${ }^{23}$ This belief actually raises several critical questions, one of which is whether if someone writes a book? Is he also motivated by revelation?

According to Islam, the gospel is the word of God delivered by Gabriel to Jesus in Aramaic. This is what all Muslims must believe in. As for the current Bible, beside it there is the Word of God in it there is also the word of humans, namely the four authors and writers of the letter. The language used is not the original language (Aramaic) which is the language used by the prophet Jesus, but the present language is Hebrew for the Old Testament and Greek for the New Testament. Which is then translated entirely in Latin, then to other languages (German, English, French and others including Indonesian). ${ }^{24}$

Until now, the Holy Book no longer exists, because after it was revealed, it is not immediately recorded as the Qur'an. But, what exist today are translations taken or derived from the authors of the "written work" of Christian figures in the early days. It was not the first original manuscript to be written, but only a copy of the original manuscript that was translated. Likewise with the Old Testament, the book was also written by Jewish religious scholars who only a small part of it came from the prophet concerned. So the writers of the books in the Bible came from a variety of different backgrounds. For example, among the prophets (Isaiah),

22 Abdul Jalal H. A., Ulumul Qur'an (Surabaya: Dunia Ilmu, 2000), p. 10.

${ }_{23}$ Muhammad Rasyidi, Koreksi Terhadap Dr. Harun Nasution Tentang "Islam Ditinjau dari Berbagai Aspeknya”. (Jakarta: Bulan Bintang, 1977), p. 9.

${ }^{24}$ Ugi Suharto, “Apakah al-Qur'an Memerlukan Hermeneutika?”, Tarjih; Jurnal Tarjih dan Pengembangan Pemikiran Islam, VI, Juli, 2003, p. 22-23. 
kings and prophets (Dawud), historians (kings), disciples of Jesus (Matthew), confessors of the apostle Jesus (Paul) and the common writer (Luke), and others. And in stark contrast to the Qur'an, it was written in the period of more than a thousand years since the time of Moses, $( \pm 1300 \mathrm{BC})$ until john's day ( $\pm 100 \mathrm{AD}) .^{25}$

\section{Abuse (Tahrif) in the Bible}

The Qur'an explains about these holy books, that which Allah revealed to the prophets, a few sentences have been changed from the place, ${ }^{26}$ or forgotten, ${ }^{27}$ so that there are some verses that are missing, ${ }^{28}$ or eliminated, religious leaders from among them also $\operatorname{lie}^{29}$, their handwriting that comes from their own wishful thinking or daydreams ${ }^{30}$ it is said to come from God. ${ }^{31}$ In short, the religious leaders of their circles and their priests and monks who were given the task of guarding the holy book did not perform their duties properly. ${ }^{32}$

Among the verses that have been distorted i.e., the words have been changed, the place has been added and subtracted so that the intentions and meanings change completely, among them the lordship of Jesus and the deity of the Holy Spirit, the writings of the authors which are claimed to be of God and the existence of strange verses that are impossible and very doubtful of the truth.

25 S. Ali Yasir, "Kristologi Qur'ani (al-Nashrâniyyah fi al-Qur'ân)", p. 42. Further details about this, can be read in the book Bart D. Ehrman, Misquoting Jesus; Kesalahan Penyalinan dalam Kitab Suci Perjanjian Baru (Kisab di balik Siapa yang Mengubah Alkitab dan Apa Alasannya) terj. Tome Beka (Jakarta: Gramedia Pustaka Utama, 2006).

${ }^{26}$ See Qur'an, 4:46.

${ }^{27}$ Qur'an, 5:12-14.

${ }^{28}$ Qur'an, 2:106.

${ }^{29}$ Qur'an, 3:77.

30 Qur'an, 2:73.

${ }^{31}$ Qur'an, 2:79.

${ }^{32}$ Qur'an, 5:44. 


\section{Tahrif about the Lordship of Jesus}

The essential message of the New Testament is what is mentioned in this verse: "Answer them: "Belief in the Lord Jesus Christ and you will be saved, you and your household" (Kisah Para Rasul, 16:31). ${ }^{33}$ Whereas diametrically, this kind of teaching is contrary to the basic teaching of Prophet Jesus, which teaches about the Supreme Divinity as contained in the verse:

"(28) Then a scribe, who heard Jesus and the Sadducees answer and knew that Jesus gave the right answer to the men, came to him and asked: "Which law is foremost? (29) Jesus answered: The most important law is: Listen to the Israelites, Allah our God, the Lord is one. 30 Love the Lord your God with all your strength. (31) And the second law is: Love your neighbor, like yourself, there is no other law more important than these two laws." (Markus 12: 28-31) ${ }^{34}$

And there are also other verses such as; Matius 22:34-40, Lukas 10:25-28, Ulangan 4:35 and 39; 6:4-5, and some other verses. The two groups of verses above, contradict each other, which the map justifies the lordship of Jesus and the second confirms the supreme divinity, then, which is true? To answer this, please note first that in the first verse, there is in the Acts written by Luke. Luke is not a disciple of Jesus, he is a physician. Mark and Matthew were disciples of Jesus. So from these considerations, then more trustworthy or accepted is the second group of verses written by Markus and Matius, because both were disciples of Jesus who knew and studied with him. As for the first verse, the truth is very doubtful because it was written by Lukas who never studied or met Jesus directly. ${ }^{35}$

${ }^{33}$ Lembaga Alkitab Indonesia, Alkitab; Perjanjian Baru (Jakarta: Percetakan Lembaga Al-Kitab Indonesia, 1996), p. 176.

${ }^{34}$ Lembaga Alkitab Indonesia, Alkitab; Perjanjian Baru p. 64.

35 Insan LS. Mokoginta, Sekeluarga itu Akbirnya Masuk Islam (Jakarta: Yayasan Birrul Wallidain, 2008), p. 87.

TAJDID vol. 20, No. 2, Juli - Desember 2021 | 411 
Whereas in the Qur'an itself, "Allah describes the main messages of the prophets" as follows:

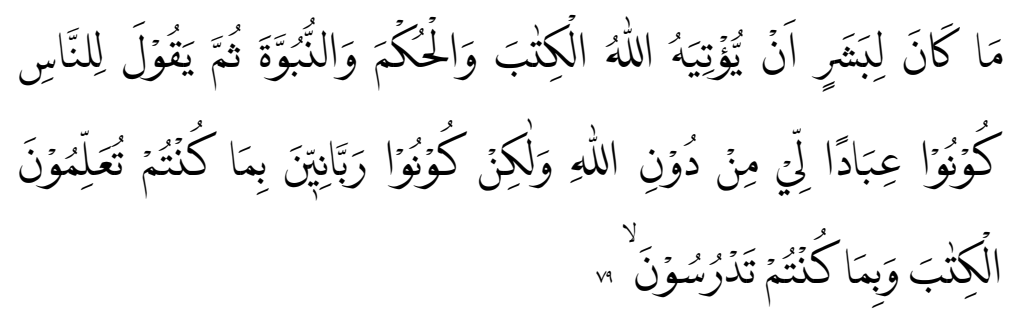

"It is not for a human [prophet] that Allah should give him the Scripture and authority and prophethood and then he would say to the people, "Be servants to me rather than Allah," but [instead, he would say], "Be pious scholars of the Lord because of what you have taught of the Scripture and because of what you have studied." (Qur'an, 3:79) ${ }^{36}$

As for the specifics regarding the Prophet Isa, Allah said:

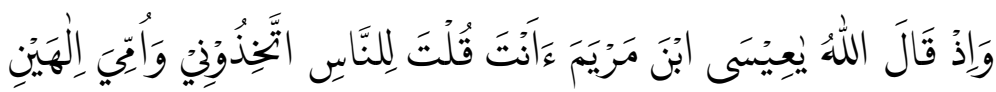

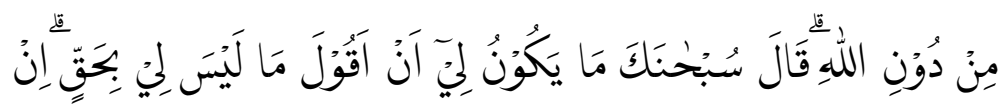

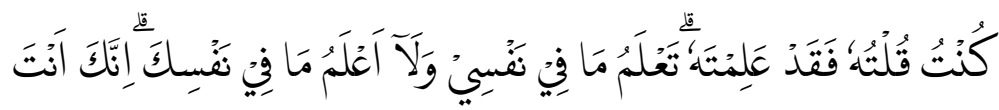

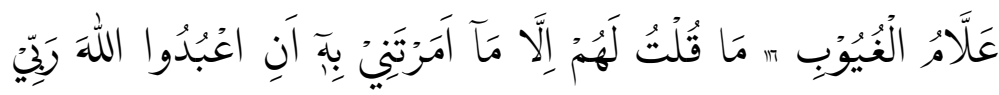

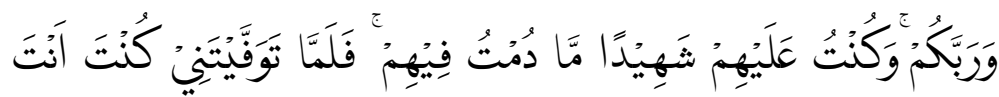

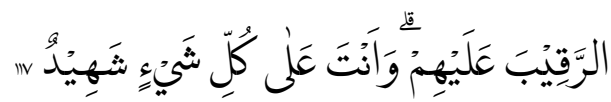

“(116) And [beware the Day] when Allah will say, "O Jesus, Son of Mary, did you say to the people, "Take me and my mother as deities besides Allah?"' He will say, "Exalted are You! It was not for me to say that to which I have no right.

36 Team Penyelenggara Penterjemah/Pentafsir Al-Qur'an Departemen Agama RI, Al-Qur'an dan Terjemahannya, p. 89. 
If I had said it, You would have known it. You know what is within myself, and I do not know what is within Yourself. Indeed, it is You who is Knower of the unseen. (117) I said not to them except what You commanded me - to worship Allah, my Lord and your Lord. And I was a witness over them as long as I was among them; but when You took me up, You were the Observer over them, and You are, over all things, Witness." (Qur'an, 5:116-117) ${ }^{37}$

\section{Tahrif about the Lordship of the Holy Spirit}

The Holy Spirit is actually Gabriel who confirms the heart of Isa al-Masih ${ }^{38}$ and to other prophets and the hearts of those who believe. ${ }^{39}$ It is also called a trusted spirit (rub al-amin), ${ }^{40}$ or our spirit (rubana), ${ }^{41}$ or the Spirit of Him (rub minhu). ${ }^{42}$ But, Christians regard him as God, the third person of the Trinity; God the Father, God the Son and the Holy Spirit. The verses on which this understanding is based are:

"(16) But when a person's heart turns to God, then the veil is taken from him. (17) For the Lord is Spirit, and where the Spirit of God is, there is freedom. (18) And we all reflect the Glory of God with an unveiled face. And "because that glory comes from God who is a Spirit, we are changed to be conformed to His image in greater and greater glory." (2 Korintus 3:16-18) ${ }^{43}$

Actually, the prophets could not teach their people to devote themselves and the angels. ${ }^{44}$ In other words, the teaching of deifying angels is not the teaching of the messenger of Allah. However, the one who actually teaches about the divinity of Jesus

37 Team Penyelenggara Penterjemah/Pentafsir Al-Qur'an Departemen Agama RI, Al-Qur'an dan Terjemahannya, p. 183.

38 Qur'an, 2:87, and 5:110.

${ }^{39}$ Qur'an, 16:102.

${ }^{40}$ Qur'an, 26:193.

41 Qur'an, 19:17.

42 Qur'an, 58:22.

${ }^{43}$ Lembaga Alkitab Indonesia, Alkitab; Perjanjian Baru p. 234.

${ }^{44}$ Huston Smith, The Religions of Man, p. 358.

TAJDID vol. 20, No. 2, Juli - Desember 2021 | 413 
and the Holy Spirit is Paul as the verse above, even though in fact he is not an apostle, but preached himself as an apostle of Jesus. ${ }^{45}$

According to the teachings of Jesus, the Holy Spirit (Yohanes 14:26) or the Spirit of Truth (Yohanes 15:26, 14:17, 16:13) who will be an entertainer (Greek: parakletos) after Jesus left the world was the Prophet Muhammad (peace be upon him) with his Qur'an. All the characteristics expressed by Jesus in Yohanes 16:1-15, it is in accordance with Prophet Muhammad and the Qur'an he brought or Jibril who delivered the Qur'an to him. The Prophet Muhammad was also named Ahmad. Ahmad's name is called By Jesus. ${ }^{46}$ As an adjective, the word Ahmad is the same as Muhammad which means a praise worthy person (Greek: periklytos is not parakletos), but Ahmad in verb form, meaning I praise the one in English translated with I glorify, so that Ahmad can be called the glorifier. Well, thus, Ahmad could be called an entertainer, a parakletos.

In the Qur'an, 2:119 and 5:19, it is affirmed that "faqad ja'akum basyir wa al-nazir" (Truly come to you an comforter and a reminder). And, in surah al-Shu'ara (42): 52, the Qur'an is called al-rub which means spirit, and in al-Isra' (17): 81, the Qur'an is called alhaqq which means truth. With the available evidence, the prediction $^{47}$ of Jesus about the coming of the Holy Spirit who glorifies him is true. ${ }^{48}$ So, in the Qur'an which was read by Jibril or the Holy Spirit it was found the glory of Jesus in the true sense. ${ }^{49}$

45 Bart D. Ehrman, Misquoting Jesus; Kesalahan Penyalinan dalam Kitab Suci Perjanjian Baru (Kisah di balik. Siapa yang Mengubah AlKitab dan Apa Alasannya), p. 6-9.

${ }^{46}$ Qur'an, 61:6.

47 Prophecy means prophecy or revelation that is revealed to the prophet to be delivered to his people. M. Dahlan Y. Al-Barry and L. Lya Sofyan Yacub, Kamus Induk Istilah Ilmiah, p. 555.

48 Prophecy means prophecy or revelation that is revealed to the prophet to be delivered to his people. M. Dahlan Y. Al-Barry and L. Lya Sofyan Yacub, Kamus Induk Istilah Imiah, p. 555.

${ }^{49}$ S. Ali Yasir, "Kristologi Qur'ani (al-Nashrâniyyah fi al-Qur'ân)”, p. 66. 
In this regard, (the doctrine of the Lordship of the Holy Spirit), God almighty explain the falsehood and falseness of the doctrine as His word:

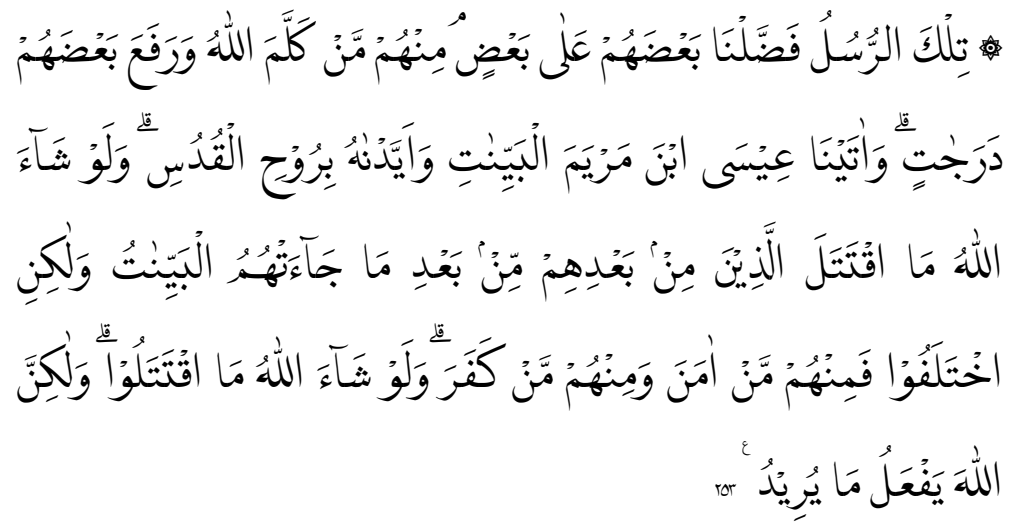

"Those messengers - some of them We caused to exceed others. Among them were those to whom Allah spoke, and He raised some of them in degree. And We gave Jesus, the Son of Mary, clear proofs, and We supported him with the Pure Spirit. If Allah had willed, those [generations] succeeding them would not have fought each other after the clear proofs had come to them. But they differed, and some of them believed and some of them disbelieved. And if Allah had willed, they would not have fought each other, but Allah does what He intends." (Qur'an, 2:253) ${ }^{50}$

\section{Claimed Handwriting Comes from God}

The Holy Scriptures before the Qur'an that exist today, in fact, are mostly human handwriting that is said to come from Allah, this is as His Word:

${ }^{50}$ Team Penyelenggara Penterjemah/Pentafsir Al-Qur'an Departemen Agama RI, Al-Qur'an dan Terjemahannya, p. 62.

TAJDID Vol. 20, No. 2, Juli - Desember 2021 | 415 


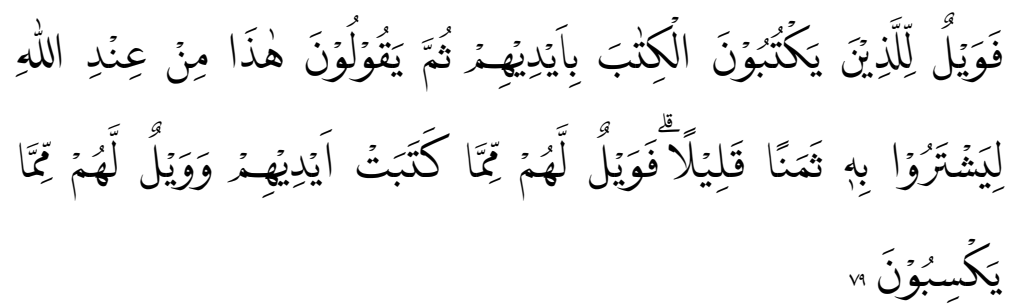

"So woe to those who write the "scripture" with their own hands, then say, "This is from Allah," in order to exchange it for a small price. Woe to them for what their hands have written and woe to them for what they earn." 51

Because the previous books had changed verses, Qur'an, 5:13, and neglected, Qur'an, 5:14, it is then recorded again with additions and subtractions that are in accordance with the tastes and passions of each author. As a result, the earlier scriptures lost their original form. This is like what happened to the Gospels, a few years after Jesus left Palestine, the Gospels have changed from their original form, in the form of stories or stories about Jesus and his teachings and his disciples. Luke, one of Paul's disciples who had never met and studied with Jesus wrote the following:

"(1) Dear Theophilus, many people have "tried to compile a message about the events that have happened among us,(2) as what was conveyed to us by them from the beginning were eyewitnesses and servants of the Word. (3) "Therefore, after I investigated all these events carefully from the beginning, I "made the decision to record them in a structured manner for you (4) so that you would know that "everything that was taught to you was true." (Lukas 1: 1-4) ${ }^{52}$

The acceptance of the Bible as the word of God is based on Paul's teaching to the Telasonic congregation. He said:

51 Team Penyelenggara Penterjemah/Pentafsir Al-Qur'an Departemen Agama RI, Al-Qur'an dan Terjemahannya, p. 23.

${ }^{52}$ Lembaga Alkitab Indonesia, Alkitab; Perjanjian Baru, p. 72.

416 | TAJDID Vol. 20, No. 2, Juli - Desember 2021 
"(4) And we know brethren beloved by God, that he has chosen you, (5) because the gospel that we preach, was not sent to you, by words alone but also by the power of the Spirit Holy and with firm assurance." (1 Tesalonika 1: 4-5) ${ }^{53}$

There are also verses 1 of Thessalonians 2:13 and 1 Corinthians 2:11-16 which are presented to the Corinthians.

According to J. R. Dummelow in the Bible Commentary, he said that at first "the writers of the Bible wrote it in Greek, whereas the teachings of Jesus were spoken in" Aramaic. In addition, sometimes a copyist does not include what is in the text, but instead he enters what should not be in the text. He only believes in his own fickle mind, or even the text is adapted to the school he holds. Likewise, Seno Harbangan said that Christians recognize and accept the Bible as the Word of God, but because the Bible was compiled by humans, the writers realized that he compiled his writings in the language he mastered, also based on knowledge. He has according to his abilities and expertise. ${ }^{54}$

The evidence above confirms that the signal of Allah in the Qur'an is true (Qur'an, 2:79). Could it be that Paul and Luke who had never studied and met or knew Jesus had the knowledge and thoughts of Jesus? Allah's word is true that it is just their daydream, (Qur'an, 2:111) or they're just guessing (Qur'an, 2:78).

\section{There are Strange Verses.}

The meaning of the strange verses here are the verses that explain something that is so impossible to happen so that the truth is very doubtful. As stated by Peter, who is one of Jesus' disciples, he said that the verses are "thumb up stories". The verses that are referred to as fake stories in the previous books are reasonable because the scriptures have been mixed with human

${ }^{53}$ Lembaga Alkitab Indonesia, Alkitab; Perjanjian Baru, p. 263.

${ }^{54}$ Maulana Muhammad Ali, Qur'an Suci terj. M. Bachrun (Jakarta: Darul Kutubil Islamiyah, 1979), p. 47. 
interpretations which according to adherents are believed that the writers were always under the guidance of the Holy Spirit. ${ }^{55}$

As for examples of verses that are impossible or strange, such as the verse which explains that the Prophet Noah was drunk (Genesis 9:18-29), Prophet Lut slept with his two daughters (Genesis 19:30-38), Prophet Aaron worshiping idols (Genesis 32:1-6), about the creation of the universe (Genesis 1:1-2:4), the resurrection of the skeletons of saints and many others. ${ }^{56}$

These stories have really tarnished the holiness of the prophets and messengers of Allah. They are saints, ${ }^{57}$ even though they are holy people. And it's really strange the story about the resurrection of the skeletons of the saints, who are the saints? And who are the townspeople they meet? Even though Allah Swt has confirmed that people who have died, it is impossible to live again in the world. ${ }^{58}$

\section{There are Verses that Contradict Each Other}

In the Bible, there are not only verses whose content is strange but also found verses that contradict each other and are very much different when talking about the same problem. This fact proves that the verses are not pure from God but that there is already human intervention. Allah has made it clear that in His words there can be no contradictions as His words:

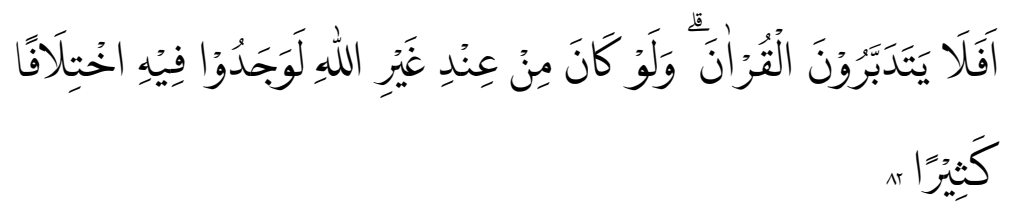

55 See 2 Petrus 2: 3, Lembaga Alkitab Indonesia, Kabar Baik untuk Masa Kini; Perjanjian Baru dalam Bahasa Indonesia Sehari-Hari (Jakarta: Lembaga Alkitab Indonesia, 1978), p. 610-611.

${ }^{56}$ S. Ali Yasir, "Kristologi Qur'ani (al-Nashrâniyyah fi al-Qur'ân)", p. 68-74.

${ }^{57}$ Qur'an, 21:24-27.

${ }^{58}$ Qur'an, 36:31.

418 | TAJDID vol. 20, No. 2, Juli - Desember 2021 
“Then do they not reflect upon the Qur'an? If it had been from [any] other than Allah, they would have found within it much contradiction." (Qur'an, 4:82) ${ }^{59}$

Among the contradictory verses is a verse that describes the son of Benjamin (Bilangan 26:38-41, 1 Tawarikh 7:6, and 8:1-2); about the strongman (Dawud) (2 Samuel 23:8 and 1 Tawarikh 11:11); about the genealogy of Jesus (Lukas 3:23-34 and Matius 1:1-17); about Jesus the cross whisperer (Matius 27:32-33, Markus 15:20b-22, Lukas 23:26-33, and Yohanes 19:17-18); about Jesus' rise to heaven (Markus 16:19-20, Lukas 24:51, Kisah Para Rasul 1:9-11, Yohanes 3:13); about the place of Aaron's death (Bilangan 33:38-39, and Ulangan 10:6-7); about David's genealogy (1 Samuel 16:10-13, and 1 Tawarikh 2:13-15); and many more verses in the Bible are contradictory to each other in one case, even certain verses also vary simply because of different editions of the publication. $^{60}$

\section{Criticism of Moqsith's Thoughts on the Confession of Existence and Biblical Truth}

Moqsith Ghazali and other liberal Islamic thinkers, while understanding the verses on which he relied in strengthening his arguments, he did not quote or rely on the opinions of the mufasir who specifically and comprehensively reviewed the verse. He only included the opinion of the Qurthubi in interpreting the word alnabiyyun on Qur'an, 5:48, and the opinion of Ibn Katsir which states that in the time of the Prophet PBUH, many Jews abandoned the law of Torah and explanations from Muhammad Syatha al-Dimyathi who gave information about the number of scriptures which Allah has revealed to His prophets. ${ }^{61}$

59 Team Penyelenggara Penterjemah/Pentafsir Al-Qur'an Departemen Agama RI, Al-Qur'an dan Terjemahannya, p. 132.

${ }^{60}$ S. Ali Yasir, "Kristologi Qur'ani (al-Nashrâniyyah fi al-Qur'ân)", p. 79.

${ }^{61}$ Abdul Moqsith Ghazali, Argumen Pluralisme Agama, p. 243. 
Moqsith forgot or maybe didn't know that in order to understand the verses above, it cannot be separated from the verses before and after because all of them are an arrangement of verses and are interrelated with one another and also cannot be separated from the causes/events or socio-historical circumstances and conditions of the revelation of the verse. In the ulum al-Qur'an, the term munasabah baina al-ayah wa al-ayah wa munasabab baina alsurah wa al-sura (correlation/relationship between verse and verse and letter and letter), and the term asbab al-nuzal (the reason for the revelation of the Qur'an) which is very helpful in understanding or interpreting a verse. ${ }^{63}$ But, this is not done by Moqsith.

So, what is said by Fahmi Salim (an expert in commentary on the graduates of Al-Azhar Cairo) is true. According to him, Moqsith interprets the verses of the Qur'an without methodological measures that can be accounted for in the discipline of science of interpretation. Contextual schools are emphasized for a number of texts which are alleged to be antireligious. And, on the other hand, the literal school is applied to

${ }^{62}$ There is an interesting phenomenon in understanding the text of the Qur'an among Muslims. Some of them have the view that "the understanding of the verses of the Qur'an must be adapted to the context in which the verses of the Qur'an were revealed. Based on this view, the rule used is al-ibrab bi khusus al-sabab la bi 'umum al-lafar. which means that the collection of meaning is based on the specificity of the cause of the revelation, not based on the generality of the words. While some others argue the opposite, namely "the understanding of the Qur'an must be based on the generality of lafaz and not on the specifics of the way it was revealed. The rules used are al-ibrah bi 'umum al-lafaz la bi khusus al-sabab. See Supiana dan M. Karman, Ulum al-Qur'an dan Pengenalan Metodologi Tafsir (Bandung: Pustaka Islamika, 2002), p. 127. In fact, not all of the verses of the Qur'an have a sabab al-nuzul, therefore al-Ja'bari states that the Qur'an was revealed in two parts. The first part is in the form of principles that are not tied to special causes, but pure instructions for humans to the way of Allah (truth) and the second part, revealed based on a cause. Look Manna Khalil al-Qattan, Mabahis fi 'Ulum al-Qur'an terj. Studi Ilmu-Ilmu al-Qur'an oleh Mudzakir AS, p. 107.

63 Muhammad Chirzin, al-Qur'an dan Ulumul Qur'an (Yogyakarta: Dana Bhakti Prima Yasa, 1998), p. 50. 
verses that support pluralism. ${ }^{64}$ The result is indeed proven, when Moqsith understands the verse of Qur'an, 5:46-66, he is so textual and literal without linking this verse with other verses both before and after or other verses that have a correlation. He also did not explain the causes or events behind the revelation of this verse (sabab al-nuгu).

It was narrated from Imam Muslim, Imam Ahmad and others that the reason or event behind the revelation of these verses, namely, the Jews sent people to ask the Prophet Muhammad for a fatwa, but with a note that the fatwa from Rasulullah saw is ordered the adulterer to be dried in the sun and beaten according to the law they set, then the fatwa was accepted, but if Rasul saw give a fatwa so that the adulteress is punished by stoning, then they must reject the fatwa. Therefore, this verse came down (Qur'an, 5:41-45) which gives a warning about the laws that Allah Swt has sent down. ${ }^{65}$

Muhammad Rashid Rida said that to interpret the verses above, (as quoted by Yusuf al-Qaradawi) it is necessary to understand that the verses above explain the Torah which is a guide for the Children of Israel, but they do not practice it and also about the Gospel and its people. Then after explaining this, the next verse mentions about the revelation of the Qur'an and its virtue and wisdom from the revelation of the Qur'an. ${ }^{66}$ When interpreting the Qur'an, 5:44, Rashid Rida said that the Torah was revealed to Musa contains instructions in matters of faith and law. With these instructions, the Children of Israel were freed from the worship of idols that was then practiced by the Egyptians. With

64 Tiar Anwar Bachtiar, "Pluralisme Agama" in Harian Republika, Jumat, 20 Maret 2009, p. 4.

65 Qomaruddin Shalih et all., Asbabun Nuzul; Latar Belakang Historis Turunnya ayat-ayat al-Qur'an (Bandung: CV. Diponegoro, 1995), p. 184.

66 Yusuf al-Qaradhawi, Hadyu al-Islam Fatawi al-Mu'ashirah, Fatwa-Fatwa Kontemporer terj. Abdul Hayyie al-Kattani et all. (Jakarta: Gema Insani Press, 2002), p. 215. 
this light of guidance, they see the path of liberation in religion and in the life of the world.

In Rashid Rida's opinion, the word al-nabiyyun al-lazina aslamu are the prophets of the Bani Israel after the Prophet Musa, within a certain period of time which expires with the sending of Prophet Isa as. They are the prophets who surrender sincerely to Allah. They decide the case for the Jews with the Torah because the Torah is a special Shariah for them and not for the whole community. As Jesus said, he said that "I was sent to the lost sheep of Israel." ${ }^{67}$

${ }^{67}$ The mission of Jesus' teachings, is actually only limited to the people of the Children of Israel or their people. This, as clearly stated by Jesus himself in the Bible namely in the Gospel of Matthew 10: 5-6; "The twelve disciples were sent by Jesus and he ordered them: "Do not stray into the paths of other nations or enter the cities of the Samaritans, but go to the sheep which are lost from the house of Israel". In the Gospel of Matthew 15:24, it is also mentioned; Jesus answered: "I was sent only to the lost sheep of the house of Israel." In addition, in the Qur'an QS. al-Shaff (61) verse 6, Allah swt. said:

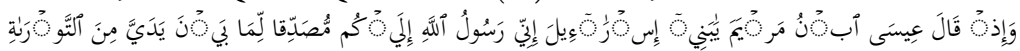

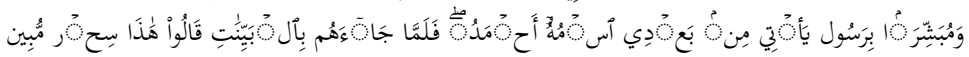

"And (remember) when Jesus Ibn Maryam said: "O Children of Israel, indeed I am the messenger of Allah to you, confirming the book before me, namely the Torah, and giving glad tidings of (the arrival of) an Apostle who will come after me, whose name is Ahmad (Muhammad)." So when the Apostle came to them with clear evidence, they said: "This is real magic." (Q.S. al-Shaff (61): 6)

However, Paul, as the founder of Christianity as listed in the Bible, namely Acts 11:24-26, actually deviated the teachings of Jesus by spreading Christianity out of Israel as the words of Paul in the Bible, namely in Ephesians 3:8 and also in Gospel Matthew 28:19 and Gospel of Mark 16:15 and in Acts 18:6. The teachings of the Bible which mostly contain Paul's teachings, have deviated and differed principally from the teachings of the Prophet Isa as. (Jesus) who teaches the religion of Tawheed (Unity of God), while Paul among others teaches the doctrine of the Trinity, atonement for sins and makes Jesus as God. Paul was not a disciple of Jesus and never knew Jesus, so almost all of Paul's teachings are different and even contradictory to the teachings of Jesus. Paul had changed Judaism as a religion for the Children of Israel into a world religion. Paul by opposing the teachings of Jesus and Jesus' disciples became a pioneer in spreading religion to pagans (outside the Children of Israel) and also changed the teachings of Jews, including circumcision (Galatians 5:2) and teaches his own teachings listed in the Bible now. In essence, almost all the teachings of Paul, derived from Greek myths and Paganism. Look Zahir Khan, in the 
Furthermore, Rashid Rida interprets Qur'an, 5:48-49, according to him, these verses are a complement to the previous verses. In this verse, Allah explains about the revelation of the Torah, then, the Gospel for the Children of Israel which contains light and instructions and commands to carry out what is in it. In addition, it also mentions about God's wrath for their sins and the disobedience of those who do not use both (Torah and Gospel) in deciding a case. Then in the next verse, Allah explains about the revelation of the Qur'an to the cover of the prophets and apostles, namely Muhammad and its position compared to the previous books.

Therefore, it can be concluded that the verses mentioned earlier are the introduction and intermediary, while this Qur'an, $5: 48-49$, is the goal and the result. ${ }^{68}$ That is the confirmation that after the revelation of the Torah was revealed to the Prophet Musa and the Bible to Prophet Isa, then Allah sent down the Qur'an which confirms (mushaddiq) and is a witness (syahid) and supervisor (raqib)-mubaiminan 'alaib-by explaining the truth as when the two books are lowered before there are deviations, subtractions, and additions. And in the verse, the wisdom is explained that every ummah in the continuity of prophethood has its own shariah (rules) and manhaj.

When interpreting the Qur'an, 5:44, al-Syinqithi explains that in this verse, Allah informed that the priests and monks were asked to keep the book of Allah, which was entrusted to them and was asked to guard it. Allah does not explain here whether they carried out the order and kept it or did not carry it out and wasted it. However, in another verse, Allah explained that they did not carry out the order and did not keep what they were asked to

Preface to the book Insan LS. Mokoginta, Sekeluarga itu Akhirnya Masuk Islam (Jakarta: Yayasan Birrul Wallidain, 2008), p. ix-xii.

${ }^{68}$ Yusuf al-Qaradhawi, Hadyu al-Islam Fatawi al-Mu'ashirah, p. 216-218. 
guard it, but they changed it intentionally, ${ }^{69}$ as which is explained in the following verse, namely, Qur'an, 4:46, 5:41, 6:91, 2:79, and 3:78, and other verses.

Al-Syinqithy explained about the difference between the Torah and the Qur'an, according to him, in fact each of them is the Word of God which was revealed to an apostle from Allah's messengers. However, the Torah has undergone changes, while the Qur'an is protected from all changes. If there is someone who dares to add or subtract just one letter in it, then thousands of Muslims will immediately know and correct it. This is one of the many miracles of the Qur'an compared to other holy books. He also opposed that God entrusted the Torah and asked the monks and priests to guard it and in fact they betrayed the trust and did not fulfill even wasted it. However, with respect to the Qur'an, Allah does not leave it to anyone because Allah alone will protect it as He says in Qur'an, 15:9, and also in Qur'an, 41:42, and other verses. $^{70}$

According to al-Syinqithi, after Allah explained that after the end of the period of the prophets, adherents, and implementers of the contents of the Torah, Prophet Jesus was sent. Who was also ordered to follow in the footsteps of the prophets of the former Israelites, namely carrying out the Torah which had been revealed previously. Who perfects the contents of the Torah which has ended its validity period and time, to be adapted to the situation and condition of the people and society. On Qur'an, 5:44, Allah explains that the Bible is full of instructions and teachings, values that can save people from error which also confirms the previous scriptures (Torah). This verse also announced the emergence of a prophet named Muhammad who has noble qualities, his shariah is more perfect and universal (comprehensive) not limited by time and place.

69 Al-Syinqithi, Tafsir Adwa' al-Bayân; Tafsir al-Qur'an dengan al-Qur'an terj. Muhammad et all. (Jakarta; Pustaka Azzam, 2007), p. 141-142.

${ }^{70}$ Al-Syinqithi, Tafsir Adwa' al-Bayân, p. 142. 
In Qur'an, 5:47, Allah ordered the followers of the Bible (followers of the Shariah of the Prophet Jesus as) to carry out the contents of the Bible until the arrival of Prophet Muhammad and so that they will judge according to what has been revealed in it and not be distorted and interpreted as they please their passions like the shariah people of Prophet Musa who disobeyed. But in fact they also disobey, they distort the meaning and content. They changed, added, reduced and adapted it to their lustful desires, so that the original Bible book is no longer known its existence. ${ }^{71}$

According to al-Maraghi, Qur'an, 5:44-47, explains that after Allah explained how surprising the behavior of the Jews who did not want to use the law, even though they knew, then asked the Prophet so that they decide their case, which they accept with pleasure if it is in accordance with their desires, and if it is not in accordance with their will, they reject the decision, then Allah explains about the Torah itself. Namely, the Torah was sent down to the Children of Israel as a guide, but apparently, they did not want to use it. They prioritize the taste of lust over religious guidance, and that is what makes them blind and do not see the light of the Qur'an. ${ }^{72}$

71 Tim Tashih Departemen Agama and UII, Al-Qur'an dan Tafsirnya (Yogyakarta: Dana Bhakti Wakaf, 1990), Jilid II, Juz 4-5-6, p. 449-450.

72 Ahmad Musthafa al-Maraghi, Tafsir al-Maraghi terj. Bahrun Abu Bakar et all. (Semarang: Toha Putra, 1987), Jilid 6, p. 219. According to the analysis of some scholars, the arrival of the Prophet Muhammad as a prophet and apostle has been explained in the books that came down before the Qur'an. In Tekad magazine, issue Number 34/Year I, 22-27 June 1999, contains an article entitled "Muhammad Juga Nabi Umat Hindu". Among other things, it states that the Professor of Languages at Alahabad University as well as a Hindu priest in India, Vaid Parkash, found the fact that in the Vedas, it was explained about the coming of the Prophet Muhammad. In the book it is also stated that the Prophet Muhammad. is a prophet and apostle who was sent to all mankind. That said, the priest called for Hindus to immediately embrace Islam. See Burhanuddin Daja et all., Agama Kita; Perspektif Sejarah Agama-Agama (Sebuab Pengantar) (Yogyakarta: Kurnia Kalam Semesta, 2000), p. 113. In the Old Testament it is explained that the Prophet Muhammad is a prophet from the descendants of the Prophet Ibrahim from the line of Ishmael as in the book of 
Thus, Moqsith's opinion, which states that the Qur'an which was revealed to the Prophet, is to function as a justification (mushaddiq) for the two books (Torah and the Bible), as a form of open acknowledgment from Muslims against these previous books, it can be accepted, of course with a note that the Torah and the Bible which are still original as when they were revealed to the Prophet Musa and Prophet Isa which have not experienced deviations and changes in the form of additions and subtractions.

As for his opinion which states that the Qur'an gives recognition to Jews and Christians. In a sense, it is enough for them to use their respective holy books as their moral support, in the current context, it is not appropriate, because after the arrival of the Prophet Muhammad and the revelation of the Qur'an, then they (Jews and Christians) are obliged to acknowledge and believe and follow the teachings brought by the Prophet Muhammad.

While his opinion says that it is an obligation for Muslims to believe in the previous prophets and apostles, including Prophet Musa and Isa who was the bearer of religion before the Prophet Muhammad is acceptable, but with a note, the religion that he

Genesis 12:1-3; 13:15, 17:20, 16:10-12, dan 21:13, 18. And also in the book of Habakkuk 3:3, kitab Ulangan 18:16-20, Yesaya 42:1, 4, Yeremia 31:31,32 and Daniel 2:38-45. In the New Testament books, especially the Gospels of Matthew, Luke, Mark and Yahya, the advent of the Prophet Muhammad is not implied because the four Gospels are actually the result of the reflection of the four writers about Jesus. But in the Bible written by Barnabas, a friend of the disciples of Jesus, the coming of the Prophet Muhammad clearly explained in articles 96-97. The Gospel of Barnabas was written based on the message and testament which is said to have been heard directly by Barnabas from Jesus. The content of the Gospel of Barnabas is much or even very different from the four New Testament Gospels. Since the 4th century AD, the Gospel of Barnabas was declared apocryphal and was not accepted by the church. For more details, read Muhammad Izzat Ismail al-Thanthawi, Mubammad Nabiyy al-Islam fi alTaurah wa al-Injil wa al-Qur'an, Rahasia Muhammad dalam Taurat dan Injil terj. Abu Nabil (Jakarta: Bina Rena Pariwara), read also The Gospel of Barnabas; Injil yang Membenarkan Kerasulan Mubammad saw terj. Achmad Kahfi (Surabaya: Bina Ilmu, tt.) 
brought was Islam, not the religion of Judaism and Christianity as recognized by its adherents.

Based on the interpretation of the Qur'an, 5:48, and strengthened by the fatwa of the Permanent Institution for Scientific Research and the Fatwa of the Kingdom of Saudi Arabia which states that in the Islamic creed, the Qur'an is the last book that was revealed by Allah who cancels the books that were sent down before; Torah, Zabur, Gospel and others. ${ }^{73}$ This is, as also explained by Rashid Rida that Jews and Christians have forgotten and omitted most of these books and distorted ${ }^{74}$ and interpreted wrongly according to their lust for the remaining part of the book. $^{75}$

\section{Conclusion}

From the explanation presented above, it can be seen that when interpreting these verses, Moqsith did not at all explain or mention changes, additions, subtractions, and deviations committed by Jews and Christians. Likewise about their disobedience to the command of Allah to follow the teachings and instructions contained in their book (Torah and Gospel) and also to judge by the rules contained in it.

Moqsith also did not explain the instructions for the coming of the Prophet Muhammad with its more perfect and universal shariah which must be followed and obeyed by them, which is contained in their book. So it is not surprising if he concludes that they that is, the Jews are sufficient to judge by the Torah which is in their hands, as well as the Christians, who are said to be sufficient to judge by the Bible.

${ }^{73}$ Lajnah Tetap untuk Penelitian Ilmiyah dan Fatwa Kerajaan Arab Saudi, Pluralisme Agama terj. Erwandi Tarmizi (tkp.: Maktabah Dakwah dan Bimbingan Jaliyat Rabwah, 2007), p. 1-2.

74 Distortion is interference, distraction and distortion of facts. see M. Dahlan Y. Al-Barry and L. Lya Sofyan Yacub, Kamus Induk Istilah Ilmiah, p. 147.

${ }^{75}$ Yusuf al-Qaradhawi, Hadyu al-Islâm Fatawî al-Mu'ashirah, p. 219. 


\section{References}

Al-Barry, M. Dahlan Y. and Yacub, L. Lya Sofyan. Kamus Induk Istilah Ilmiah; Seri Intelektual. Surabaya: Target Press, 2003.

Daja, Burhanuddin et al.. Agama Kita; Perspektif Sejarah AgamaAgama (Sebuah Pengantar). Yogyakarta: Kurnia Kalam Semesta, 2000.

D. Ehrman,Bart. Misquoting Jesus; Kesalahan Penyalinan dalam Kitab Suci Perjanjian Baru (Kisah di Balik Siapa yang Mengubah AlKitab dan Apa Alasannya) terj. Tome Beka. Jakarta: Gramedia Pustaka Utama, 2006.

Ghazali, Abdul Moqsith. Argumen Pluralisme Agama; Membangun Toleransi Berbasis Al-Qur'an. Jakarta: Kata Kita, 2009.

Husaini, Adian. "Problem Teks Bible dan Hermeneutika" Majalah Pemikiran dan Peradaban Islam; Islamia, I, Maret, 2004.

Ilyas, Yunahar. "Menyoal Pluralisme Agama", Tabligb; Menyatukan Visi dan Misi Umat, vol. 2. No. 09, April 2004.

Jalal H. A.. Abdul Ulumul Qur'an. Surabaya: Dunia Ilmu, 2000.

Lajnah Tetap untuk Penelitian Ilmiyah dan Fatwa Kerajaan Arab Saudi, Pluralisme Agama terj. Erwandi Tarmizi. tkp.: Maktabah Dakwah dan Bimbingan Jaliyat Rabwah, 2007.

Lembaga Alkitab Indonesia. Alkitab; Perjanjian Baru. Jakarta: Percetakan Lembaga Al-Kitab Indonesia, 1996.

Kabar Baik untuk Masa Kini; Perjanjian Baru dalam Bahasa Indonesia Sehari-Hari. Jakarta: Lembaga Alkitab Indonesia, 1978.

Madjid, Nurcholish. Pintu-Pintu Menuju Tuhan. Jakarta: Paramadina, 1994.

Fiqib Lintas Agama; Membangun Masyarakat InklusifPluralis. Jakarta:Paramadina, 2004.

Al-Maraghi, Ahmad Musthafa. Tafsir al-Maraghi terj. Bahrun Abu Bakar et al.. Semarang: Toha Putra, 1987.

Mokoginta, Insan LS. Sekeluarga itu Akhirnya Masuk Islam. Jakarta: Yayasan Birrul Wallidain, 2008.

428 | TAJDID vol. 20, No. 2, Juli - Desember 2021 
Muhammad Ali, Maulana. Qur'an Suci terj. M. Bachrun. Jakarta: Darul Kutubil Islamiyah, 1979.

Al-Qaradhawi, Yusuf. Hadyu al-Islâm Fatawi al-Mu'ashirah, FatwaFatwa Kontemporer terj. Abdul Hayyie al-Kattani et all.. Jakarta: Gema Insani Press, 2002.

Al-Qaththân, Mannâ' Khalîl. Mabâhis fi 'Ulum al-Qur'ân. Riyâdh: Muassasah al-Risâlah, 1976.

Mabâhis fi 'Ulum al-Qur'ân terj. Studi Ilmu-Ilmu alQur'an oleh Mudzakir AS. Jakarta: Litera Antar Nusa, 2007.

Rasyidi, Muhammad. Koreksi Terbadap Dr. Harun Nasution Tentang "Islam Ditinjau dari Berbagai Aspeknya". Jakarta: Bulan Bintang, 1977.

Al-Shaffâr, Hasan. al-Ta'addudiyât wa al-Huriyat fi al-Islâm. Beirut: Dâr al-Bayan al-'Arabi, 1990.

Shabîh al-Bukhari. al-Maktabah al-Syâmilah Solo: Pustaka Ridwana, 2008.

Shahîh Muslim. al-Maktabah al-Syâmilah Solo: Pustaka Ridwana, 2008

Shalih, Qomaruddin et all., Asbabun Nu₹ul; Latar Belakang Historis Turunnya ayat-ayat al-Qur'an. Bandung: CV. Diponegoro, 1995.

Smith, Huston. The Religions of Man, Agama-Agama Manusia terj. Saafroodin Bahar. Jakarta: Yayasan Obor Indonesia, 2004.

Suharto, Ugi. “Apakah al-Qur'an Memerlukan Hermeneutika?”, Tarjib; Jurnal Tarjih dan Pengembangan Pemikiran Islam, VI, Juli, 2003.

Supiana dan M. Karman. Ulum al-Qur'an dan Pengenalan Metodologi Tafsir. Bandung: Pustaka Islamika, 2002.

Al-Syinqithi. Tafsir Adwa' al-Bayân; Tafsir al-Qur'an dengan al-Qur'an terj. Muhammad et all. Jakarta; Pustaka Azzam, 2007.

Team Penyelenggara Penterjemah/Pentafsir Al-Qur'an Departemen Agama RI, Al-Qur'an dan Terjemahannya. Jakarta: Yayasan Penyelenggara Penterjemah/Pentafsir Al-Qur'an Departemen Agama RI, 1971. 
Asep Setiawan

Al-Thanthawi, Muhammad Izzat Ismail. Muhammad Nabiyy al-Islâm fí al-Taurah wa al-Injîl wa al-Qur'ân, Rahasia Muhammad dalam Taurat dan Injil terj. Abu Nabil. Jakarta: Bina Rena Pariwara, 1997.

Tim Tashih Departemen Agama dan UII. Al-Qur'an dan Tafsirnya Jilid II, Juz 4-5-6. Yogyakarta: Dana Bhakti Wakaf, 1990.

Tim Tafsir Departemen Agama RI. Al-Qur'an dan Tafsirnya. Jilid I. Jakarta: Departemen Agama RI, 2004.

Yasir, S. Ali. "Kristologi Qur'ani (al-Nashraniyyah fi al-Qur'ân)". Modul Kristologi Islami Departemen Agama Daerah Istimewa Yogyakarta, Yogyakarta, 1988. 